\title{
MONITORING METAL POLLUTION LEVELS IN MINE WASTES AROUND A COAL MINE SITE USING GIS
}

\author{
D. Sanliyuksel Yucel ${ }^{a}$, M. A. Yucel ${ }^{\text {b* }}$, B. Ileri ${ }^{\mathrm{c}}$ \\ ${ }^{a}$ Canakkale Onsekiz Mart University, Engineering Faculty, Department of Mining Engineering, 17100 Canakkale, Turkey \\ denizsyuksel@comu.edu.tr \\ ${ }^{\mathrm{b}}$ Canakkale Onsekiz Mart University, Engineering Faculty, Department of Geomatics Engineering, 17100 Canakkale, Turkey \\ aliyucel@comu.edu.tr \\ ${ }^{c}$ Canakkale Onsekiz Mart University, Engineering Faculty, Department of Environmental Engineering, 17100 Canakkale, Turkey \\ burcuileri@comu.edu.tr
}

KEY WORDS: Acid mine drainage/lake, coal mine, GIS, metal pollution, mine waste

\begin{abstract}
:
In this case study, metal pollution levels in mine wastes at a coal mine site in Etili coal mine (Can coal basin, NW Turkey) are evaluated using geographical information system (GIS) tools. Etili coal mine was operated since the 1980s as an open pit. Acid mine drainage is the main environmental problem around the coal mine. The main environmental contamination source is mine wastes stored around the mine site. Mine wastes were dumped over an extensive area along the riverbeds, and are now abandoned. Mine waste samples were homogenously taken at 10 locations within the sampling area of 102.33 ha. The paste $\mathrm{pH}$ and electrical conductivity values of mine wastes ranged from 2.87 to 4.17 and 432 to $2430 \mu \mathrm{S} / \mathrm{cm}$, respectively. Maximum $\mathrm{Al}, \mathrm{Fe}, \mathrm{Mn}, \mathrm{Pb}, \mathrm{Zn}$ and $\mathrm{Ni}$ concentrations of wastes were measured as 109300, 70600, 309.86, 115.2, 38 and $5.3 \mathrm{mg} / \mathrm{kg}$, respectively. The $\mathrm{Al}, \mathrm{Fe}$ and $\mathrm{Pb}$ concentrations of mine wastes are higher than world surface rock average values. The geochemical analysis results from the study area were presented in the form of maps. The GIS based environmental database will serve as a reference study for our future work.
\end{abstract}

\section{INTRODUCTION}

Operation of mines resulting in mine wastes poses a significant risk to the surrounding environment (Rashed, 2010). Acid mine drainage (AMD) forms a very important concern where mine waste containing metal-rich sulphides from mining activity are stored and/or abandoned (Concas et al., 2006). Improper management of mine wastes results in the migration of heavy metals to the surrounding environment, contributing to the contamination of soil substrates, destruction of soil texture, shortage of nutrients, destruction of ecological landscape, groundwater pollution and decreases in biological diversity (Rashed, 2010). The Can coal basin (NW Turkey) is rich in lignite $(100 \mathrm{Mt})$, though these reserves, known as Can coals, cannot be described as quality coals due to low calorific value and high sulphur content (max: 14.36 wt.\%) (Gurdal and Bozcu, 2011). Etili coal mine located in Can coal basin has been operated as an open pit mine (Figure 1). The Etili coal mine wastes have been left without any management. Mine pits fill with surface and groundwater over time and transform into acid mine lakes (Figure 2). Acid mine lakes are located upstream of Kocabas stream, and several residential areas along this stream supply their drinking water from boreholes (Yucel and Turan, 2016). Acid mine lakes with the low $\mathrm{pH}$ (2.59) and high electrical conductivity $(6.43 \mathrm{mS} / \mathrm{cm})$ values, in addition to high sulphate $(5370 \mathrm{mg} / \mathrm{L})$ and high metal concentrations (Al, $\mathrm{Fe}, \mathrm{Mn}$, etc.) create environmental problems (Sanliyuksel Yucel et al., 2016). The creeks surrounding the mine lakes in Etili coal mine have low $\mathrm{pH}$ values varying from 2.85 to 5.75 and their waters are red-brown in colour (Sanliyuksel Yucel and Baba, 2013). The mine wastes cover a large area and cause environmental risks as the reduction in grain size increases surface area and accelerate the process of AMD generation. The purpose of this study was to evaluate metal pollution levels in mine wastes at Etili coal mine using geographical information system (GIS) tools.

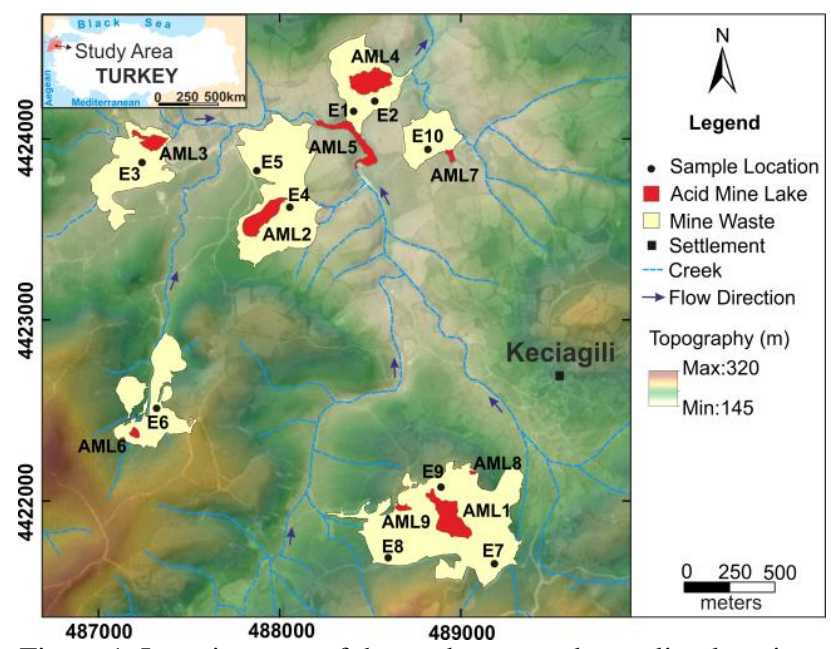

Figure 1. Location map of the study area and sampling locations

\section{MATERIALS AND METHODS}

$\mathrm{pH}$ and electrical conductivity $(\mathrm{EC}, \mu \mathrm{S} / \mathrm{cm})$ values of 9 acid mine lakes were measured in situ using WTW 340i multiparameter. Ten mine waste samples (E1 to E10) were collected from Etili coal mine site at depths from 0 to $15 \mathrm{~cm}$ (see Figure 1). Paste $\mathrm{pH}$ values of mine wastes were measured in the laboratory using the Sobek et al. (1978) method. Metal contents of mine wastes were determined by means of inductively coupled plasma mass spectrometry (SCIEX-ELAN 9000; PerkinElmer) at AcmeLabs (Canada). The satellite images (CNES/Airbus) of the study area from July 2016 were 
uploaded to ArcGIS $10.3 \mathrm{v}$ software. Universal Transverse Mercator (UTM) projection Zone 35 with World Geodetic System of 1984 (WGS84) datum coordinates was used. The boundaries of acid mine lakes and mine wastes were digitized on the satellite images. Using digital elevation model (DEM) data from the field, a three-dimensional (3D) digital land model was created for the study area. Sample locations were geometrically located on the map using its coordinates. Attribute data of the sample points were obtained from analysis results. The $\mathrm{pH}, \mathrm{EC}$ values and metal concentration analysis results of mine waste samples were visualized on the map to create thematic maps for each type of data.

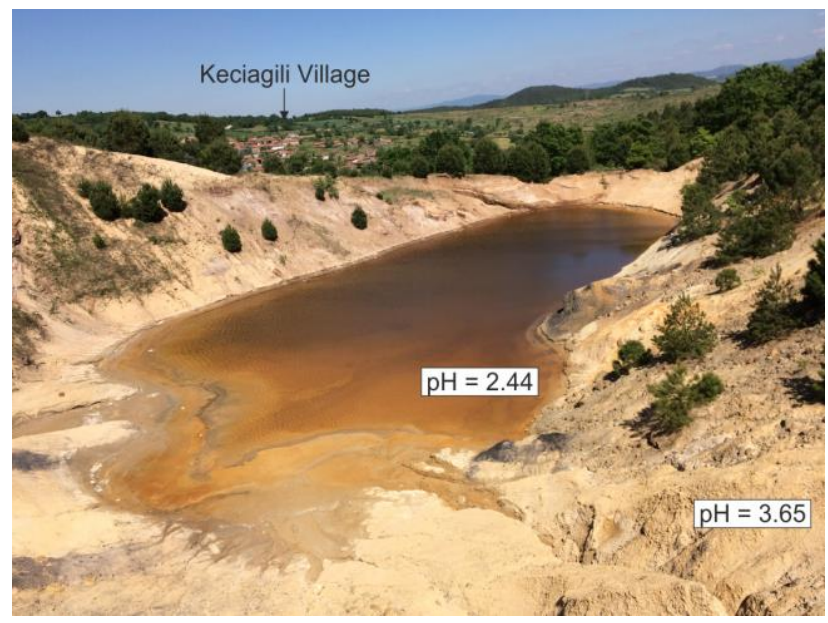

Figure 2. Snapshot from acid mine lake and mine wastes

\section{RESULTS AND DISCUSSION}

Dogru and Yucel (2017) calculated the mine waste area using RGB 6/7 5/4 7/5 band combination on 2013 Landsat 8 satellite image for the Etili mine site and stated the area of the mine wastes was 103.75 ha. Using Pleiades satellite images from July 2016, the total area of acid mine lakes and mine waste in Etili coal mine was calculated to be 10.95 and 102.33 ha, respectively. $\mathrm{pH}$ and $\mathrm{EC}$ value of acid mine lakes ranged from 2.34 to 6.0 and 2800 to $6640 \mu \mathrm{S} / \mathrm{cm}$, respectively (Table 1 ). Sanliyuksel Yucel and Yucel (2017) reported that maximum Al, $\mathrm{Fe}$, and $\mathrm{Mn}$ concentrations of acid mine lakes were measured as 445.62, 389.56, and $165.52 \mathrm{mg} / \mathrm{l}$, respectively.

The paste $\mathrm{pH}$ and $\mathrm{EC}$ values of mine wastes ranged from 2.87 to 4.17 and 432 to $2430 \mu \mathrm{S} / \mathrm{cm}$, respectively (Figure 3 and 4). The low $\mathrm{pH}$ dissolves the metals and increases remobilization and spatial distribution. The mine wastes are mineralogically composed of quartz, cristobalite, pyrite, opal-CT, gypsum, and illite/mica-, kaolinite-, chlorite-, and feldspar-group minerals, in addition to jarosite and alunite (Sanliyuksel Yucel and Baba, 2016). Carbonate-group minerals were not determined in the research area. Only silicate minerals, which are harder to dissolve and act as a buffer when dissolved, were determined (Sanliyuksel Yucel and Baba, 2016). Lack of carbonate minerals in mine wastes also increases the occurrence of AMD.

\begin{tabular}{cccccc}
\hline $\begin{array}{c}\text { Sample } \\
\text { name }\end{array}$ & $\mathbf{p H}$ & $\begin{array}{c}\text { EC } \\
\boldsymbol{\mu S} / \mathbf{c m}\end{array}$ & Mine lakes & $\mathbf{p H}$ & $\begin{array}{c}\mathbf{E C} \\
\boldsymbol{\mu S} / \mathbf{c m}\end{array}$ \\
\hline E1 & 2.87 & 2350 & AML1 & 2.75 & 4220 \\
E2 & 3.66 & 514 & AML2 & 2.55 & 6640 \\
E3 & 3.13 & 2430 & AML3 & 2.92 & 2800 \\
E4 & 3.56 & 784 & AML4 & 2.91 & 3360 \\
E5 & 4.17 & 432 & AML5 & 2.58 & 3320 \\
E6 & 3.5 & 972 & AML6 & 6.0 & 2950 \\
E7 & 3.66 & 506 & AML7 & 2.78 & 3120 \\
E8 & 3.91 & 637 & AML8 & 2.44 & 6290 \\
E9 & 3.65 & 525 & AML9 & 2.34 & 5860 \\
E10 & 3.96 & 683 & & & \\
\hline Minimum & 2.87 & 432 & & 2.34 & 2800 \\
Mean & 3.60 & 983.3 & & 3.03 & 4284 \\
Median & 3.65 & 660 & & 2.75 & 3360 \\
Maximum & 4.17 & 2430 & & 6.0 & 6640 \\
\hline
\end{tabular}

Table 1. $\mathrm{pH}$ and EC values of mine wastes and acid mine lakes

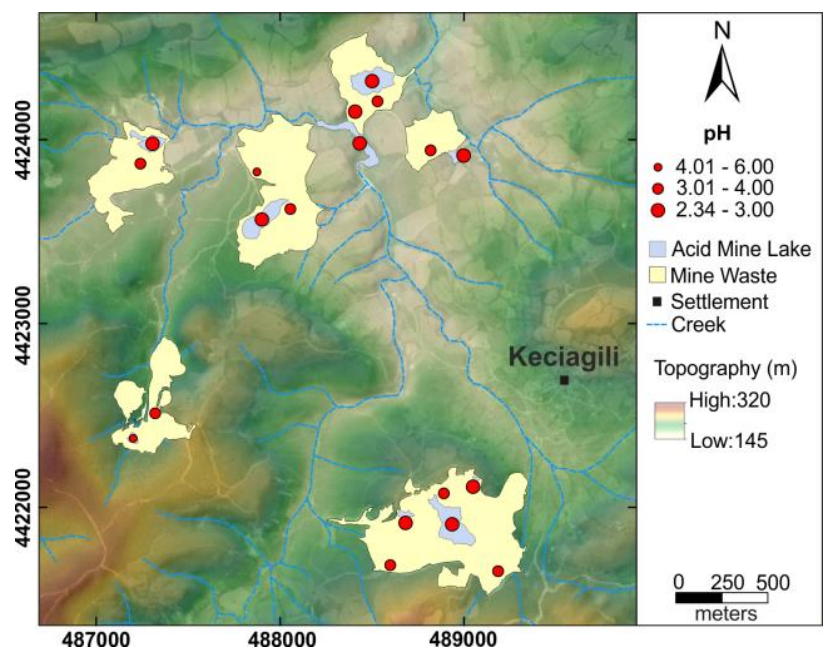

Figure 3. $\mathrm{pH}$ distribution of mine wastes and acid mine lakes

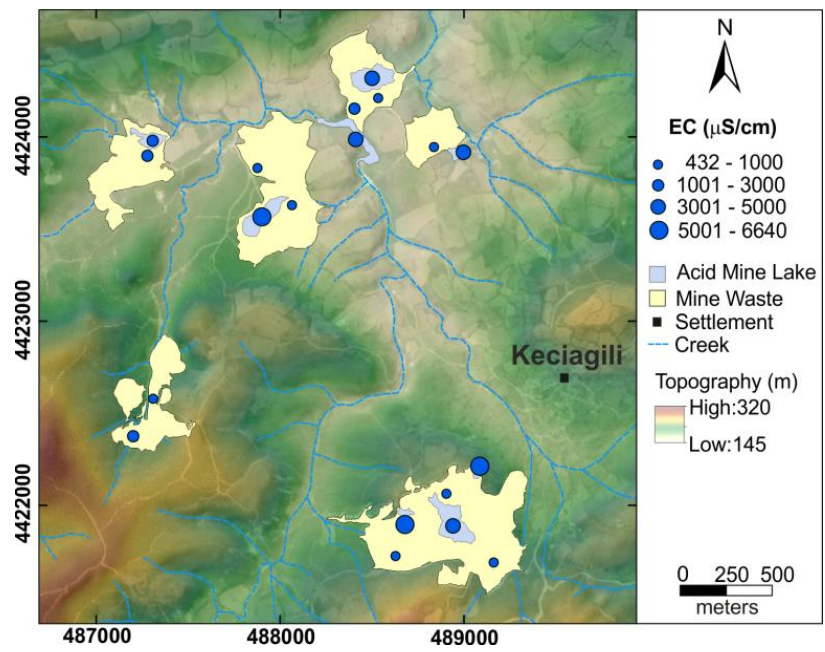

Figure 4. EC distribution of mine wastes and acid mine lakes 
The sequences of metal concentration in mine wastes generally are as follows: $\mathrm{Al}>\mathrm{Fe}>\mathrm{Mn}>\mathrm{Pb}>\mathrm{Zn}>\mathrm{Ni}$, respectively (Table 2). The maximum $\mathrm{Al}, \mathrm{Fe}, \mathrm{Mn}, \mathrm{Ni}, \mathrm{Pb}$ and $\mathrm{Zn}$ concentration of mine wastes reach $109300,70600,309.86,5.3,115.2$, and 38 $\mathrm{mg} / \mathrm{kg}$, respectively. Figure 5 displays the thematic map in the GIS environment based on maximum and minimum metal concentration interval of the mine wastes. The thematic maps allow better comprehension and perception of the location and spatial aspects of the obtained analysis results. The $\mathrm{Al}, \mathrm{Fe}$ and $\mathrm{Pb}$ concentration of mine wastes are higher than world surface rock average values calculated by Martin and Meybeck (1979). Gurdal (2011) reported that the average concentration of $\mathrm{Pb}$ in coal $(24 \mathrm{mg} / \mathrm{kg})$ in the Etili coal mine is higher than the world average value $(7.8 \mathrm{mg} / \mathrm{kg})$ determined by Ketris and Yudovich (2009). Finkelman (1994) stated that lead occurs in coal predominantly as sulphides or associated with sulphide minerals. The high $\mathrm{Al}$ concentration is related to weathering of aluminosilicate minerals from the regional rocks (Sanliyuksel Yucel et al., 2014). Pyrite is common sulphur mineral in all of the volcanic and sedimentary rocks and mine wastes and is the main cause of high Fe concentration and acidity in the Etili coal mine (Sanliyuksel Yucel et al., 2016).

\begin{tabular}{ccccccc}
\hline \multirow{2}{*}{$\begin{array}{c}\text { Sample } \\
\text { name }\end{array}$} & $\mathbf{A l}$ & $\mathbf{F e}$ & $\mathbf{M n}$ & $\mathbf{N i}$ & $\mathbf{P b}$ & $\mathbf{Z n}$ \\
\cline { 2 - 7 } E1 & 88800 & 59600 & $\mathbf{m g} / \mathbf{k g}$ & & & \\
E2 & 91100 & 66700 & 154.93 & 2.1 & 115.2 & 15 \\
E3 & 83700 & 49200 & 77.46 & 2.5 & 41.3 & 24 \\
E4 & 102800 & 43600 & 77.46 & 4.1 & 53.7 & 30 \\
E5 & 79400 & 33300 & 154.93 & 4.8 & 39.1 & 27 \\
E6 & 91800 & 47700 & 77.46 & 1.6 & 26 & 22 \\
E7 & 86900 & 70600 & 232.39 & 5.3 & 24.7 & 17 \\
E8 & 92700 & 40800 & 154.93 & 2.7 & 38.5 & 24 \\
E9 & 109300 & 52000 & 77.46 & 1 & 36 & 18 \\
E10 & 101000 & 38400 & 309.86 & 1.8 & 28.2 & 35 \\
\hline Minimum & 79400 & 33300 & 77.46 & 1 & 24.7 & 15 \\
Mean & 92750 & 50190 & 139.43 & 2.96 & 49.74 & 25 \\
Median & 91450 & 48450 & 116.19 & 2.6 & 38.8 & 24 \\
Maximum & 109300 & 70600 & 309.86 & 5.3 & 115.2 & 38 \\
WSRA* & 69000 & 35900 & 750 & 49 & 16 & 127 \\
\hline
\end{tabular}

WSRA: World surface rock average value,

*Martin and Meybeck (1979)

Table 2. Some metal concentrations of mine wastes
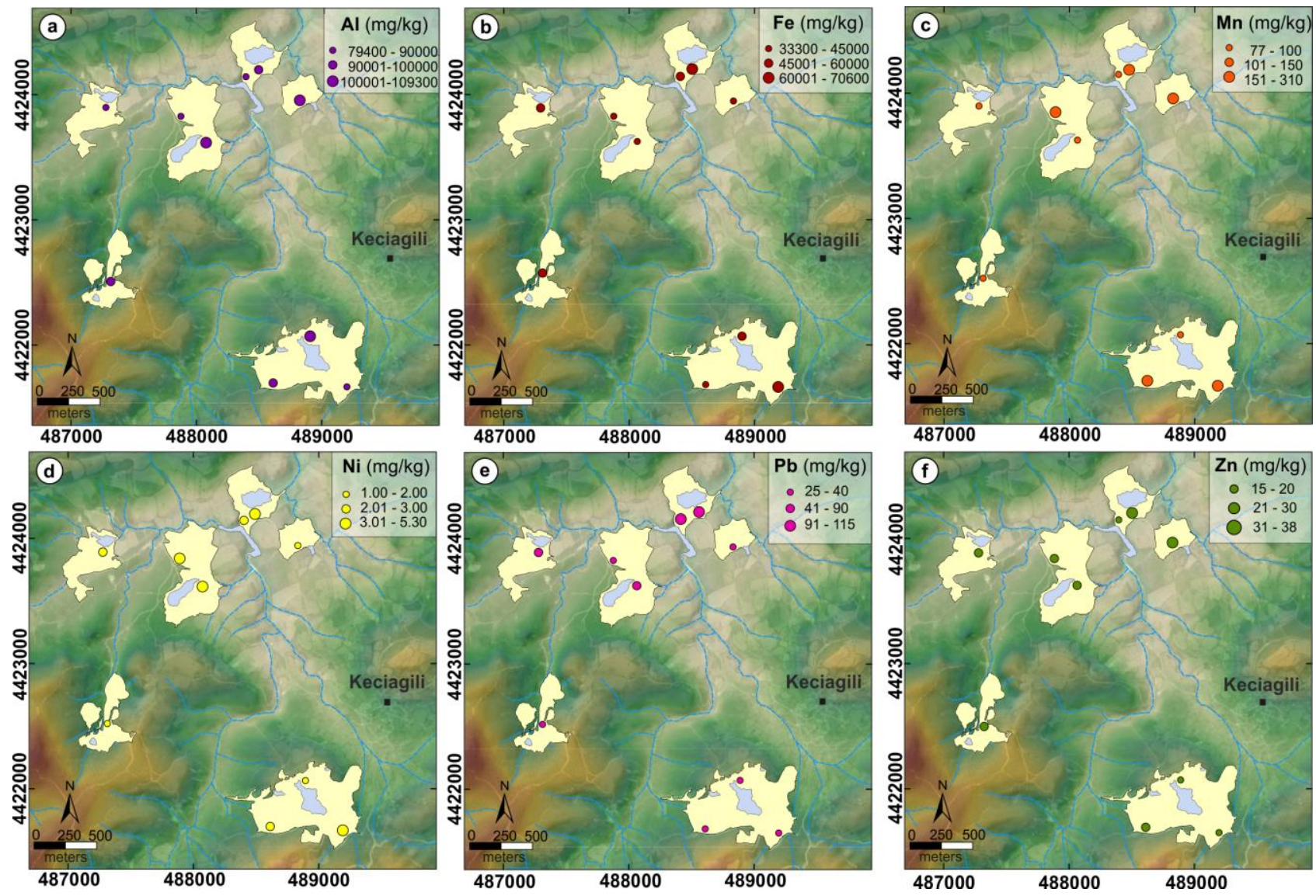

Figure 5. Metal concentration of mine wastes a. $\mathrm{Al} \mathrm{b.} \mathrm{Fe} \mathrm{c.} \mathrm{Mn} \mathrm{d.} \mathrm{Ni} \mathrm{e.} \mathrm{Pb} \mathrm{f.} \mathrm{Zn}$

\section{CONCLUSION}

For the determination of metal pollution levels of mine wastes caused by mining activities, ten waste samples were taken and geochemically analyzed from Etili coal mine. The $\mathrm{Al}, \mathrm{Fe}$ and $\mathrm{Pb}$ concentrations of mine wastes are higher than world surface rock average values. The geochemical analysis results were presented in the form of maps. This study demonstrated the efficiency of integrating geochemical data and using GIS technologies when assessing the environmental impact of mine sites. The results of this case study may be used in further 
studies for environmental risk assessment of mining waste facilities.

\section{ACKNOWLEDGEMENTS}

This study was financially supported by the Canakkale Onsekiz Mart University Scientific Research Projects Coordination Unit, Turkey (FBA-2016-759).

\section{REFERENCES}

Concas, A., Ardau, C., Cristini, A., Zuddas, P., Cao. G., 2006. Mobility of heavy metals from tailings to stream waters in a mining activity contaminated site. Chemosphere 63, pp. 244 253.

Dogru, M., Yucel, M.A., 2017. Lithological Mapping Using LANDSAT 8 OLI Multispectral Data, Afyon Kocatepe University Journal of Science and Engineering. 17(1), pp. 172184.

Gurdal, G., 2011. Abundances and modes of occurrence of trace elements in the Çan coals (Miocene), Çanakkale-Turkey. International Journal of Coal Geology, 87, pp. 157-173.

Gurdal, G., Bozcu, M., 2011. Petrographic characteristics and depositional environment of Miocene Can coals, CanakkaleTurkey. International Journal of Coal Geology, 85, pp. 143160.

Finkelman, R.B., 1994. The use of modes of occurrence hazardous elements in coal: levels of confidence. Fuel Processing Technology, 39, pp. 21-34.

Ketris, M.P., Yudovich, Y.E., 2009. Estimations of Clarkes for carbonaceous biolithes: world average for trace element contents in black shales and coals. International Journal of Coal Geology, 78, pp. 135-148.

Martin, J.M., Meybeck, M., 1979. Elemental Mass-Balance of Material Carried by Major World Rivers. Marine Chemistry, 7(3), pp. 173-206.

Rashed, M.N., 2010. Monitoring of contaminated toxic and heavy metals, from mine tailings through age accumulation, in soil and some wild plants at Southeast Egypt. Journal of Hazardous Materials, 178, pp. 739-746.

Sanliyuksel Yucel, D., Baba, A., 2013. Geochemical characterization of acid mine lakes and their effect on the environment, NW of Turkey. Archives of Environmental Contamination and Toxicology, 64(3), pp. 357-376.

Sanliyuksel Yucel, D., Yucel, M.A., Baba, A., 2014. Change detection and visualization of acid mine lakes using time series satellite image data in geographic information systems (GIS): Can (Canakkale) County, NW Turkey. Environmental Earth Sciences, 72(11), pp. 4311-4323.

Sanliyuksel Yucel, D., Balci, N., Baba, A., 2016. Generation of Acid Mine Lakes Associated with Abandoned Coal Mines in Northwest Turkey. Archives of Environmental Contamination and Toxicology, 70(4), pp. 757-782.

Sanliyuksel Yucel, D., Baba, A., 2016. Prediction of acid mine drainage generation potential of various lithologies using static tests: Etili coal mine (NW Turkey) as a case study. Environmental Monitoring and Assessment, 188(8), pp. 473 (16).

Sanliyuksel, Yucel, D., Yucel, M.A., 2017. Determining hydrochemical characteristics of mine lakes from abandoned coal mines and 3D modelling of them using unmanned aerial vehicle. Pamukkale University Journal of Engineering Sciences, doi:10.5505/pajes.2016.37431.

Sobek, A.A., Schuller, W.A., Freeman, J.R., Smith, R.M., 1978. Field and laboratory methods applicable to overburdens and mine soils. US EPA-600/2-78-054, Cincinnati, OH, USA.

Yucel, M.A., Turan, R.Y., 2016. Areal Change Detection and 3D Modeling of Mine Lakes Using High-Resolution Unmanned Aerial Vehicle Images. Arabian Journal for Science and Engineering, 41(12), pp. 4867-4878. 